\title{
The Effect of Trade Openness and Investment Realization on Inclusive Economic Growth in Cities and Districts of East Java in 2015-2019
}

\author{
Farida Rahmawati*, Silvi Dewi Purwanti, Nadiah Ramadhani \\ Faculty of Economics and Business, State University of Malang, Indonesia
}

*Corresponding author:

E-mail:

farida.rahmawati.fe@um.ac.id

\begin{abstract}
Economic growth is hoped to have a positive impact and also increase the welfare of the community. a good inclusive economic growth requires a study on this matter, it can be started by looking at what factors can fulfill inclusive economic growth. So, this research aims to know the inclusive economic growth of cities and districts in East Java in 2015-2019 and to look at the factors that can influence the achievement of inclusive economic growth. The research method used is the calculation of inclusive growth created by UNDP and panel data linear regression analysis. In 2019, all regions at the level were filled by districts, while the city was still at the intermediate level. The results of the regression analysis show that trade openness and investment realization affect the inclusive economic growth of cities and districts in East Java in 2015-2019.
\end{abstract}

Keywords: Inclusive growth, trade openness, investment realization

\section{Introduction}

Inclusive economic growth is a process that ensures equal access to economic opportunities for all people regardless of the situation of each individual (Badan Pusat Statistik, 2016). The concept of an inclusive economy is a concept that provides a broader picture of the existence of economic growth which has been the benchmark for the progress of a country or region. An inclusive economy provides a picture that focuses on the impact of economic growth. With high economic growth, it is expected to have a positive impact or increase the welfare of the community evenly regardless of the class of each individual.

To know about this issue, several world and national institutions have made calculations regarding inclusiveness. One of them is the United Nation Development Program (UNDP) which makes calculations with indicators of poverty, inequality, and employment (Sitorus \& Arsani, 2018)

In addition to the calculation of inclusive growth which gives results in the form of an inclusive index, some factors influence the level of achievement of the index. The factors driving inclusive growth are foreign investment and trade openness. Another factor that can influence inclusive economic growth is government policies that can improve welfare through increased investment.

Studies on the inclusiveness of economic growth at the regional (regional) level are also very necessary because of the different characteristics between regions, not only at the national level. So that understanding and insight into dynamics can also be seen broadly and can optimize the role of government.

So to bridge the gap above, in the research conducted, namely by trying to analyze economic growth at the regional (regional) level, especially using data on cities and districts, cities and districts of East Java as a case study. Also, to be able to see what supports inclusive growth and how inclusive economic growth can be maximally achieved, a study is needed that can be started by looking at the factors that can influence the components of inclusive economic growth itself.

\section{How to cite:}

Rahmawati, F., Purwanti, S. D., \& Ramadhani, N. (2021). The effect of trade openness and investment realization on inclusive economic growth in cities and districts of East Java in 2015-2019. $1^{\text {st }}$ ICEMAC 2020: International Conference on Economics, Management, and Accounting. NST Proceedings. pages 246-255. doi: 10.11594/ nstp.2021.1030 
Several things affect economic growth, namely capital stock, labor, and technological progress. In this case, capital or capital accumulation has an important role in economic growth. Based on research by Ramadhan and Setiadi (2019), the physical capital instrument used in this research is an investment. According to (Ramadhan \& Setiadi, 2019) the government continues to strive to spur quality economic growth both regionally and nationally by increasing the value of the investment by providing and revising related regulations that can hamper and also continue to carry out infrastructure development, especially in areas that are still lagging.

Several things influence or encourage inclusive growth, namely foreign investment and trade openness. Trade openness has a significant effect on inclusive economic growth in Indonesia in 2016. According to Khan et al. (2016) trade openness is a facility for the movement of labor and also companies in improving and developing the sector-sector which has increased demand. In the current era of globalization, the role of trade openness has the potential to improve the economy, both for individuals and companies. Therefore, the role of trade openness in the economy, especially for the achievement of inclusive economic growth, is very important, the positive impact of technological developments through trade openness can open up access to fulfillment of needs between regions. When an area can meet basic needs equally, economic activities can run quickly and there is support from technological developments used by companies or for individuals. With this, equality can be achieved and can accelerate economic growth, thus leading to the accelerated achievement of inclusive economic growth.

\section{Material and Methods}

This study uses 2 research variables: The dependent variable in this study is an index of the inclusiveness of cities/districts in East Java in 2015-2019 and the independent variables in this study are the openness of trade in cities/districts in East Java in 2015-2019 and investment realization (PMA and PMDN) of cities/districts in East Java in 2015-2019.

This type of research is descriptive quantitative research, using quantitative research, the researcher will prove the previous theories that are relevant to the current research topic by examining objects in real terms. And the purpose of descriptive research here is to provide a more detailed description of a phenomenon and symptoms that are happening.

\section{Data types and sources}

The data used in this method is secondary panel data from cities and districts in East Java in 20152019. The data used in this research are:

1. Inclusiveness index of cities and districts in East Java 2015-2019 using the UNDP calculation method. The data used to form this index is data on the percentage of cities and districts poor in East Java 2015-2019, the cities and districts Gini ratio in East Java 2015-2019, and the cities and districts open unemployment rate in East Java in 2015-2019. This data is obtained from the Badan Pusat Statistik East Java province.

2. Trade openness uses data on the proportion between the value of exports and imports to the GRDP value of cities and districts in East Java in 2015-2019 which were obtained from the Badan Pusat Statistik cities and districts in East Java Province.

3. Investment realization data (foreign investment and domestic investment) of cities and districts in East Java in 2015-2019 obtained from the Badan Koordinasi Penanaman Modal (BKPM).

\section{Data analysis method}

The measurement of inclusive economic growth from this study uses the calculation method created by the United Nation Development Program (UNDP). This calculation uses a simple average of the three indicators used, poverty (percentage of poor people), inequality (Gini ratio), and labor (inverse ratio of employment to population). However, due to limited data at the cities and districts level, the inverse ratio of employment to population is replaced by the open unemployment rate (Sitorus \& Arsani, 2018). The data has different units so that it must be normalized by the formula: 
$Z i=\left(\frac{X i-X i(\min )}{X i(\max )-X i(\min )}\right)$

Information:

- Zi: normalized value

- Xi: data to be normalized (observed value)

- Xi (min): the smallest data value in the observation

- $\mathrm{Xi}(\max )$ : the largest data value in the observation

After the data has been normalized, the inclusive index value will be calculated using a simple average formula:

$I=\frac{1}{3}(Z i$ poverty $+Z i$ inequality $+\mathrm{Zi} \mathrm{labor})$

Ramos, et al (2013) classifies the inclusiveness index in the following ranges:

- $0-0.2$ : very high

- $0.2-0.4 \quad$ : high

- $0.4-0.6 \quad$ : medium

- $0.6-0.8 \quad$ : low

- $0.8-1 \quad$ : bad

The second method in this research is multiple linear regression analysis of panel data. From the results of this analysis, it can be seen the relationship between the independent variables and the dependent variable. According to Gujarati \& Porter (Ramadhan \& Setiadi, 2019), there are several stages in panel data regression analysis, namely first by determining the specification of the model to be used in the research, then selecting the best model including the common effect, fixed effect and random effect model and by doing Chow test, Hausman test and BP-LM test. After obtaining the most appropriate model and suitable estimation method, then the steps that will be taken in this analysis are:

1. Perform independent variable regression, namely trade openness and investment realization (foreign investment and domestic investment) with the dependent variable of inclusive economic growth.

Then the regression equation model to be used is:

$$
\text { IPEIi, } \mathrm{t}=\boldsymbol{\beta 0}+\boldsymbol{\beta 1 T 0 i ,} \mathrm{t}+\boldsymbol{\beta 2 F I i , t}+\boldsymbol{\beta} \text { DIi, } \mathrm{t}+\varepsilon
$$

Information:

- IPEI $\quad$ Inclusive Economic Growth Index for cities and districts $\mathrm{i}$ in the period $\mathrm{t}$ (percent)

- TOi, $\mathrm{t} \quad$ : Trade Openness of cities and districts i in period $\mathrm{t}$ (percent)

- $\quad$ B2FIi, $t$ : foreign investment cities and districts i in period $t$ (thousand US \$)

- $\quad \beta 3 \mathrm{DIi}, \mathrm{t} \quad$ : Domestic investment in cities and districts $\mathrm{i}$ in period $\mathrm{t}$ (Rp billion)

- $\beta 0 \quad$ : Intercept

- $\beta \mathrm{j} \quad$ : the variable regression coefficient to $\mathrm{j}$

- $\varepsilon \quad:$ error term

2. Perform multiple linear regression coefficient test

3. Perform a classic assumption test. In a good model when the parameter estimate is Best Linear Unavailable Estimator (BLUE) includes multicollinearity test and homoscedasticity test. The 
calculation and analysis of multiple linear regression are carried out through the Eviews 9.0 software.

\begin{tabular}{|c|c|c|c|}
\hline Effects Test & Statistic & d.f. & Prob. \\
\hline Cross-section F & 10.998258 & $(37,149)$ & 0.0000 \\
\hline Cross-section Chi-square & 250.174145 & 37 & 0.0000 \\
\hline
\end{tabular}

Cross-section fixed effects test equation:

Dependent Variable: PEI

Method: Panel Least Squares

Date: 11/11/20 Time: 21:54

Sample: 20152019

Periods included: 5

Cross-sections included: 38

Total panel (balanced) observations: 190

\begin{tabular}{crcrr}
\hline \hline \multicolumn{1}{c}{ Variable } & Coefficient & Std. Error & t-Statistic & Prob. \\
\hline \hline C & 0.431988 & 0.006183 & 69.86717 & 0.0000 \\
TO & 0.001404 & 0.000374 & 3.755553 & 0.0002 \\
PMA & $-9.38 E-09$ & $4.56 E-08$ & -0.205583 & 0.8373 \\
\multicolumn{1}{c}{ PMD } & $5.83 E-09$ & $2.29 \mathrm{E}-09$ & 2.545128 & 0.0117 \\
\hline \hline R-squared & 0.129019 & Mean dependent var & 0.430526 \\
Adjusted R-squared & 0.114971 & S.D. dependent var & 0.075577 \\
S.E. of regression & 0.071100 & Akaike info criterion & -2.428635 \\
Sum squared resid & 0.940265 & Schwarz criterion & -2.360277 \\
Log likelihood & 234.7204 & Hannan-Quinn criter. & -2.400944 \\
F-statistic & 9.184120 & Durbin-Watson stat & 0.247460 \\
Prob(F-statistic) & 0.000011 & & & \\
\hline \hline
\end{tabular}

Selection of Appropriate Panel Data Regression Model

1. Chow test

H0: selected CEM model (Prob> 0.05)

H1: selected FEM model (Prob $<0.05$ )

$\mathrm{H} 1$ is accepted. $\mathrm{H} 0$ is rejected

2. Hausman Test

H0: selected REM model (Prob> 0.05)

H1: selected FEM model (Prob <0.05)

$\mathrm{H} 0$ is accepted $\mathrm{H} 1$ is rejected 
Correlated Random Effects - Hausman Test

Equation: Untitled

Test cross-section random effects

\begin{tabular}{lrrr}
\hline \hline Test Summary & Chi-Sq. Statistic & Chi-Sq. d.f. & Prob. \\
\hline \hline Cross-section random & 5.360299 & 3 & 0.1472 \\
\hline \hline
\end{tabular}

Cross-section random effects test comparisons:

\begin{tabular}{crrrr} 
Variable & Fixed & Random & $\operatorname{Var}($ Diff.) & Prob. \\
\hline \hline TO & -0.000783 & 0.001309 & 0.000003 & 0.2357 \\
PMA & 0.000000 & 0.000000 & 0.000000 & 0.7984 \\
PMDN & -0.000000 & 0.000000 & 0.000000 & 0.0614 \\
\hline \hline
\end{tabular}

Cross-section random effects test equation:

Dependent Variable: PEI

Method: Panel Least Squares

Date: $11 / 11 / 20$ Time: $21: 57$

Sample: 20152019

Periods included: 5

Cross-sections included: 38

Total panel (balanced) observations: 190

\begin{tabular}{crrrr}
\hline \hline Variable & Coefficient & Std. Error & t-Statistic & Prob. \\
\hline \hline C & 0.427071 & 0.010656 & 40.07758 & 0.0000 \\
TO & -0.000783 & 0.001886 & -0.414906 & 0.6788 \\
PMA & $1.56 \mathrm{E}-08$ & $3.17 \mathrm{E}-08$ & 0.490867 & 0.6242 \\
PMDN & $-1.23 \mathrm{E}-09$ & $2.35 \mathrm{E}-09$ & -0.523585 & 0.6013 \\
\hline \hline
\end{tabular}

3. Breusch Pagan-Lagrange Multiplier Test

Used because the two tests above are not the same

H0: selected REM model (Prob> 0.05)

H1: selected CEM model (Prob <0.05)

$\mathrm{H} 1$ is accepted. $\mathrm{H} 0$ is rejected 


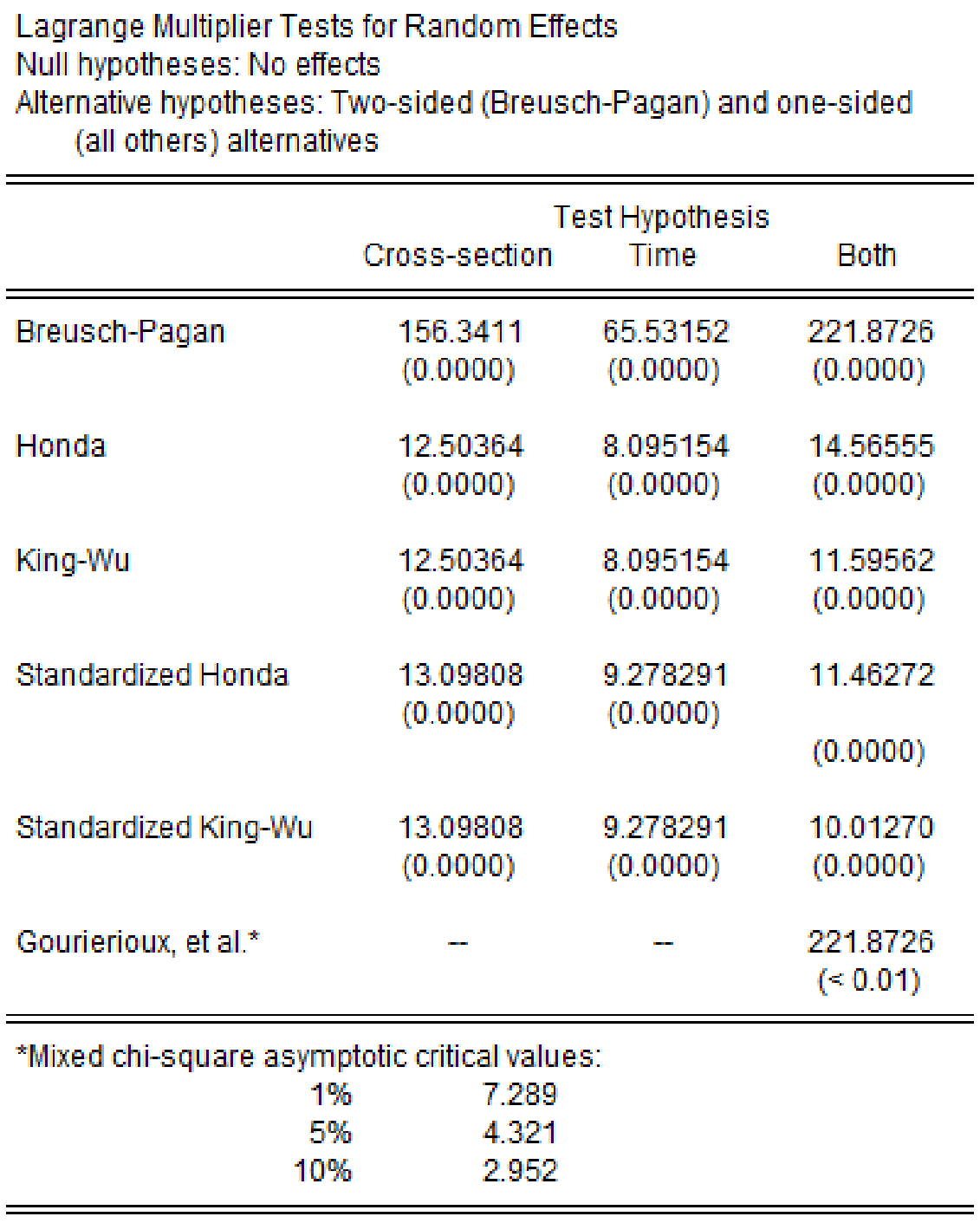

Panel data regression analysis was carried out to see the relationship and influence of trade openness variables and physical capital variables on inclusive economic growth in cities and districts in East Java in 2015-2019. There are three models in this study, namely the common effect, random effect, and fixed effect. Based on the results of the Chow test, it was found that the decision to reject $\mathrm{H} 0$ was at a significance level of 0.05 so that it could be concluded that the fixed effect model was better than the common effect. Then with the Hausman test which gives the decision to fail to reject $\mathrm{H} 0$ at a significance level of 0.05 so that the random effect model is a better model than the fixed effect. Furthermore, based on the results of the Breusch Pagan-Lagrange Multiplier test as the determinant of the best model carried out in the study, from the test results it was found that the decision to reject $\mathrm{H} 0$ at a significance level of 0.05 so that it can be concluded that the common effect model is a better estimate. From the test results in the case of this study, the best model is the common effect model. 
Analysis of Regression Equations

\begin{tabular}{|c|c|c|c|c|}
\hline $\begin{array}{l}\text { Dependent Variable: } \\
\text { Method: Panel Least } \\
\text { Date: } 11 / 11 / 20 \text { Time } \\
\text { Sample: } 20152019 \\
\text { Periods included: } 5 \\
\text { Cross-sections inclu } \\
\text { Total panel (balance }\end{array}$ & 38 & & & \\
\hline Variable & Coefficient & Std. Error & t-Statistic & Prob. \\
\hline $\mathrm{C}$ & 0.431988 & 0.006183 & 69.86717 & 0.0000 \\
\hline TO & 0.001404 & 0.000374 & 3.755553 & 0.0002 \\
\hline PMA & $-9.38 E-09$ & $4.56 \mathrm{E}-08$ & -0.205583 & 0.8373 \\
\hline PMDN & $5.83 \mathrm{E}-09$ & $2.29 \mathrm{E}-09$ & 2.545128 & 0.0117 \\
\hline R-squared & 0.129019 & Mean depen & ent var & 0.430526 \\
\hline Adjusted R-squared & 0.114971 & S.D. depend & ntvar & 0.075577 \\
\hline S.E. of regression & 0.071100 & Akaike info $\mathrm{c}$ & terion & -2.428635 \\
\hline Sum squared resid & 0.940265 & Schwarz crite & ion & -2.360277 \\
\hline Log likelihood & 234.7204 & Hannan-Quil & n criter. & -2.400944 \\
\hline F-statistic & 9.184120 & Durbin-Wats & n stat & 0.247460 \\
\hline Prob(F-statistic) & 0.000011 & & & \\
\hline
\end{tabular}

In the results of the model selection in this study, the most appropriate model is the common effect model, estimation in the common effect model uses the LSDV method. The regression equation obtained in this study:

$$
I P E I i, t=0.431988+0.001404 T O i, t-9.38 P M A i, t+5.83 P M D N i, t+\varepsilon
$$

Trade openness has a significant and positive effect on inclusive economic growth. With a probability value of $0.0002<0.05$. This means that when openness increases by 1 percent, inclusive economic growth will increase by 0.001404 percent on average, assuming other variables remain. The openness of trade, especially in the era of globalization can help boost technology and boost revenue because with this the community can be encouraged to continue to innovate and can also take advantage of technological developments so that they can compete globally. This is in line with the results of research from (Khan et al., 2016) that globalization affects inclusive growth through trade openness, from the results of his research showing that increasing globalization through technology leads to economies of scale which in turn can increase inclusive growth.

Foreign investment has no significant effect on inclusive economic growth. With a probability value of $0.8373>0.05$. This means that when foreign investment decreases by 1 thousand US \$, inclusive economic growth will increase by 9.38 percent on average, assuming other variables remain. According to Ramadhan and Setiadi (2019) this can happen because there is still a large contribution from the private sector (especially foreigners) aimed at the industrial sector, which is less able to absorb middle to lower workers. So that with an increase in the contribution of the private sector (especially foreigners) still affects the industrial sector by absorbing middle and upper workers. Also, according to research results from (Wibowo, 2019), local investment or domestic investment is more effective in absorbing local labor compared to foreign investment. Domestic or local investment can also support inclusive economic growth in East Java. Because according to the results of this study the PMDN variable has a 
significant and positive effect. Where the local investment is more interested in labor-intensive companies or industries. Indonesia is a country with a high population density,

according to the Central Statistics Agency in 2019 the population in Indonesia reached 268,074.6 thousand people. Especially the island of Java is one of the islands with a high population density due to its mobility and faster production of goods and services. In particular, East Java is also one of the provinces with a high population, reaching up to 39,698.6 thousand people, so that labor-intensive industries can increase efforts to absorb labor in East Java. With the absorption of labor, when the high population of productive age can be absorbed in the labor market with the support of other factors from certain sectors, it will increase output for a region, when a company's output is high and the results of high output from labor-intensive industries are supported by infrastructure. and good technology can reach a wide range of product marketing so that it will also be able to influence economic growth so that inclusive economic growth can be achieved.

Domestic investment has a significant and positive effect on inclusive economic growth. With a probability value of $0.0117<0.05$. This means that when foreign investment increases by 1 billion IDR, inclusive economic growth will increase by 5.83 percent on average, assuming other variables remain. So with the presence of domestic private investment, it can contribute to the industrial sector by encouraging the absorption of labor evenly and can be one of the factors that can encourage economic development efforts.

The results of the $\mathrm{F}$ test show that rejecting $\mathrm{H} 0$ is at a significance level of 0.05 so that the variables of trade openness, foreign investment, and domestic investment affect inclusive economic growth in East Java in 2015-2019 simultaneously. The partial test shows that the trade openness variable has a significant and positive effect on inclusive economic growth. Meanwhile, the variable that represents physical capital, namely foreign investment, has no significant effect on inclusive economic growth. And the variable that also represents human capital, namely domestic investment, has a significant and positive effect in this study. The resulting adjusted R-square value is 11.49 percent so that the ability of the variable trade openness and investment realization in explaining inclusive economic growth is 11.49 percent, the remaining is explained by other variables outside the model.

\section{Classic Assumption Test}

1. Multicollinearity Test

The correlation value between variables $<0.8$ had no symptoms of multicollinearity or was free of multicollinearity.

\begin{tabular}{|c|c|c|c|c|}
\hline \multicolumn{4}{|c|}{ Correlation } \\
\hline & TO & PMA & PMDN & \\
\hline TO & 1.000000 & 0.170424 & 0.219370 & \\
\hline PMA & 0.170424 & 1.000000 & 0.475531 & \\
\hline PMDN & 0.219370 & 0.475531 & 1.000000 & \\
\hline & & & & \\
\hline & & & & \\
\hline
\end{tabular}

2. Heteroscedasticity Test

The probability value $>0.05$, there is no heteroscedasticity. 


\begin{tabular}{|c|c|c|c|c|}
\hline \multicolumn{5}{|c|}{$\begin{array}{l}\text { Dependent Variable: RESABS } \\
\text { Method: Panel Least Squares } \\
\text { Date: } 11 / 11 / 20 \text { Time: } 22: 10 \\
\text { Sample: } 20152019 \\
\text { Periods included: } 5 \\
\text { Cross-sections included: } 38 \\
\text { Total panel (balanced) observations: } 190\end{array}$} \\
\hline Variable & Coefficient & Std. Error & t-Statistic & Prob. \\
\hline $\mathrm{C}$ & 0.056188 & 0.003765 & 14.92344 & 0.0000 \\
\hline TO & 0.000203 & 0.000228 & 0.893480 & 0.3728 \\
\hline PMA & $-1.23 \mathrm{E}-08$ & $2.78 \mathrm{E}-08$ & -0.441185 & 0.6596 \\
\hline PMDN & $9.96 \mathrm{E}-10$ & $1.40 \mathrm{E}-09$ & 0.713659 & 0.4763 \\
\hline R-squared & 0.008278 & \multicolumn{2}{|c|}{ Mean dependent var } & 0.055663 \\
\hline Adjusted R-squared & -0.007717 & \multicolumn{2}{|c|}{ S.D. dependent var } & 0.043130 \\
\hline S.E. of regression & 0.043296 & \multicolumn{2}{|c|}{ Akaike info criterion } & -3.420700 \\
\hline Sum squared resid & 0.348660 & \multicolumn{2}{|c|}{ Schwarz criterion } & -3.352342 \\
\hline Log likelihood & 328.9665 & \multicolumn{2}{|c|}{ Hannan-Quinn criter. } & -3.393009 \\
\hline F-statistic & 0.517525 & \multicolumn{2}{|c|}{ Durbin-Watson stat } & 0.493657 \\
\hline Prob(F-statistic) & 0.670716 & & & \\
\hline
\end{tabular}

The results of the non-multicollinearity assumption test, namely by looking at the results of the glacier test that the correlation value between independent variables is less than 0.8 , meaning that the non-multicollinearity assumption is fulfilled in this model. To test the non-heteroscedasticity assumption, a probability value of more than 0.05 is obtained so that it can be concluded that the non-heteroscedasticity assumption is fulfilled.

\section{Conclusion}

In the aspect of inclusiveness, cities and districts in East Java have increased every year. Regions that were in the early year, namely 2015 were still at a low level at the end of the year, have experienced an increase at the middle level, as well as some regions that were initially at the middle level have succeeded in increasing inclusiveness to a high level. In 2019, all regions at the high level were filled by districts, while the city as a whole was still at the middle level, this shows that the inclusion in the districts in East Java is still higher than in the city.

In this study, the panel data regression results obtained that the most appropriate model is the common effect model. Inclusive economic growth in the cities and districts of East Java in 2015-2019 was influenced by trade openness and realization of investment in the form of PMA and PMDN. The trade openness variable has a significant and positive effect on inclusive economic growth. Meanwhile, the variable that represents investment realization, namely PMA, has no significant effect on inclusive economic growth. The variable that also represents investment realization, namely PMDN, has a significant and positive effect in this study. So that local investment or domestic investment can accelerate the achievement of inclusive economic growth in East Java Province and can promote equitable welfare for the community compared to foreign investment or foreign investment.

Based on the conclusions of the research results obtained, the researcher's suggestions for further research use another approach and can use other variables to be able to find out what factors can affect inclusive economic growth, especially for regionally inclusive economic growth or inclusive economic growth. In the cities and districts of East Java and also with different periods.

\section{References}

Badan Pusat Statistik. (2019). Produk domestik Regional Bruto Kabupaten/Kota Jawa Timur Menurut Pengeluaran 2015-2019. 
Khan, A., Khan, G., Safdar, S., Munir, S., \& Andleeb, Z. (2016). Measurement and determinants of inclusive growth : A case study of Pakistan ( 1990-2012 ). The Pakistan Development Review, Winter, 455-466.

Ramadhan, R. R., \& Setiadi, Y. (2019). Pengaruh modal fisik dan sumber daya manusia terhadap indeks inklusif di Indonesia. Jurnal Ekonomi Pembangunan, 17(December), 109-124.

UNDP. (2017). Strategy for Inclusive and Sustainable Growth. 1-147.

Vera Yanti Sitorus, \& Marsinta Arsani. (2018). A comparative study of inter-provincial inclusive economic growth in Indonesia 2010-2015 with approach methods of ADB, WEF, and UNDP. Jurnal Perencanaan Pembangunan: The Indonesian Journal of Development Planning, 2(1), 64-77. https://doi.org/10.36574/jpp.v2i1.32

Wibowo, B. (2019). Dampak spillover dan kebijakan fiskal terhadap pencapaian pertumbuhan inklusif antar Provinsi di Indonesia. Institut Pertanian Bogor. 